\title{
Proximity politics in changing oceans
}

\author{
Paul Foley $^{1}$
}

Received: 27 April 2021 / Accepted: 29 November 2021 / Published online: 22 December 2021

(c) The Author(s) 2021

\begin{abstract}
How will ocean governance actors and institutions handle a future where the abundance and spatial distribution of marine life changes rapidly and variably? The answer, this paper argues, will be influenced by inherited and changing ocean proximity politics, whereby institutions and actors use spatial proximity or adjacency to legitimize particular forms of resource control, conservation and use. Focusing on United Nations and Canadian institutional contexts and recognizing state and non-state actors as agents of policy change, the paper documents and examines why and how spatial proximity has been invoked (i) as a principle for claiming, defining and implementing use rights, privileges and responsibilities for not just nation-states but also for other entities such as coastal communities and small-scale fisheries; (ii) to justify and legitimize rights, privileges and responsibilities for their interest and benefit; and (iii) to inform and challenge global and local discussions about principles such as conservation, sustainability and distributive equity. The future practical use of spatial closeness/distance for guiding policies of access and exclusion under conditions of change will likely be influenced by challenges associated with applying multiple and conflicting governance principles, accommodating diverse interests and interpretations of principle definition and application, and multiple forms of biophysical and social mobilities. The conclusion highlights four areas of further research and policy engagement for the study of ocean proximity politics.
\end{abstract}

Keywords Governance $\cdot$ UNCLOS $\cdot$ Climate change $\cdot$ Mobility $\cdot$ Equity $\cdot$ Adjacency

\section{Introduction}

As Earth's atmosphere, cryosphere, biosphere and oceans change more rapidly, marine species are expected to be increasingly changing in abundance and geographic distribution. These shifts present a major challenge for prevailing political institutions that have asserted authority to manage interactions between society and marine fisheries (Pinsky et al. 2018). Emerging conflicts in some US fisheries, for example, are shaped in large part by the perceived proximity of coastal US states to marine species whose patterns of abundance and spatial location are subject to debate (Dubik et al. 2019). In a period of declining shrimp abundance over a wide area of the Northwest Atlantic and Labrador Sea, producers and organized interest and Indigenous groups

Paul Foley

pfoley@grenfell.mun.ca

1 Environmental Policy Institute, School of Science and the Environment, Memorial University of Newfoundland (Grenfell Campus), Corner Brook, Newfoundland and Labrador, Canada lobbied federal decision-makers by deliberating on the idea that Indigenous and coastal community proximity to shrimp along remote coastlines of Eastern Canada requires special consideration (Foley and Mather 2019). In the face of fundamental change and uncertainty, it is critical to improve our understanding of how the Earth's governance systems and interactions (Biermann 2014; Burch et al. 2019; Kooiman et al. 2008) around the world include principles and policies of closeness/distance to better understand capacities for adaptation. While non-state actors and institutions have been growing in influence in global ocean governance in recent decades (Allison 2001; Kooiman et al. 2005; Foley 2019a; Haas et al. 2021), the state-centric United Nations Convention on the Law of the Sea (UNCLOS) arguably remains the most powerful systematic attempt to govern human interactions with the spaces and biophysical components of Earth's oceans. ${ }^{1}$ This international agreement among states fundamentally redefined global social-ecological relations, including sweeping away key elements of the "freedom of the seas" concept in favor of claiming special rights and

\footnotetext{
${ }^{1}$ Sea and ocean will be used interchangeably for the purposes of this paper.
} 
responsibilities for nation-states over the exploration, use and exploitation of marine resources in new Exclusive Economic Zones (EEZs) out to 200 nautical miles adjacent to their shores (Campling and Colás 2018). It created a global framework of laws, institutions and practices defining how states might cooperate and manage different activities in and on the ocean, including access to, sharing and distribution of resources (Werle et al. 2019). Indeed, the spatial extension of state rights and responsibilities over more distant proximate seas is rooted in efforts to avoid and resolve competing colonial and inter-state claims over accessing and controlling ocean resources and spaces. A core logic of UNCLOS is to establish that coastal states-states with a sea coastline-have special entitlement to rights and responsibilities over ocean resources most proximate to their shores, mainly because they have a stronger perceived interest in adjacent resources and better capacity to regulate them (Posner and Sykes 2010: 576). For UNCLOS and parties to the agreement, proximity matters a great deal. The implications of this governance idea and the institutional forces it set in motion in the state system are not well understood, however. Enhancing understanding of the role of proximity in ocean governance will add to the body of knowledge needed for more fully understanding the capacity for those institutions to respond to climate and ocean change.

This current lack of understanding in the research community is significant because the way proximity or adjacency ${ }^{2}$ is embedded in particular ways of knowing through text, lines and laws can be ambiguous, contested and politicized. Contestation can result from the historical legacy of multiple and overlapping access claims and rights regimes from state and non-state groups and because of the different and changing interests that lay claim to coastal states' relatively recent extension of rights over ocean resources and spaces (Acheson 1975; Durrenberger and Pálsson 1987; St. Martin 2009; McCay 2011; Bavinck and Gupta 2014; Campling and Havice 2014; Gray 2018; Peters 2020; Steinberg et al. 2020). As Elizabeth Havice puts it in relation to capture fisheries, the interaction between a "temporally and spatially dynamic sovereignty" and life in the sea forces different "interests together by fluid ocean materialities and the mobile nature" of those vying for the right and privilege to capture fish for commercial purposes (Havice 2018: 1280). We therefore need more knowledge to understand the ways in which laws, in broad and pluralistic terms, have been made, contested and remade in oceans that are fluid, material and changing within and outside UNCLOS (Braverman and Johnson 2020). This paper joins others that respond to these needs to form more extended baselines for identifying, understanding and

\footnotetext{
2 This paper uses proximity and adjacency interchangeably, though the empirical analysis focuses on institutional use of the concept of adjacency.
}

responding to societal conflicts emerging as territorially based resource allocation governance systems prepare for rapid species shifts and distributional changes (Dubik et al. 2019). In order to build and share knowledge about how and why institutional commitments to particular principles emerge and change. This paper identifies how considerations of power, conservation and the equitable distribution of benefitsprinciples popular in analyses of blue growth and blue economy policy agendas that are proliferating around the world (Silver et al. 2015; Barbesgaard 2018; Lehman 2016; Daly et al. 2021; Farmery et al. 2021; Cisneros-Montemayor et al. 2021) - has also interacted powerfully with the principle of proximity. Specifically, this paper aims to examine the ways in which international and Canadian institutional policy contexts explicitly and implicitly reference proximity or adjacency to protect or defend the material and distributive interests and identities of coastal communities and small-scale fisheries.

The following analysis relies on data gathered using a desk-based and web-based rapid appraisal approach, focusing on the indirect and direct use of proximity or adjacency terms in institutional contexts of the United Nations and the Government of Canada. The United Nations was selected because of the significance of UNCLOS for fisheries policies worldwide and related UN institutions of fisheries governance that are responsive to and provide guidance to member state governments. The Government of Canada was selected as an institutional site where the concept of adjacency is specifically referred to relatively widely in policy documents (Foley et al. 2015; Bennett et al. 2018), providing a potential exemplary case where we can expect contentious politics of proximity to intensify in the coming decades. Data collection and analysis focused largely on searching for explicit and implicit references to adjacency and benefits for adjacent entities like communities and small-scale fisheries as a criterion for access and allocation in fisheries within and across formal policy and related documents. The paper then used textual analysis and narrative reconstruction to identify particular policy histories and themes.

The findings indicate that the same kind spatial proximity logic that nation-states employ to justify their claims over nearby oceans has influenced, and been influenced by, narratives about the needs and interests of coastal communities and smallscale fisheries. The analysis also finds that international and Canadian policy histories were shaped by societal forces such as fish harvester associations, a reminder that institutional policy commitments are the result of societal interactions within and beyond the state. Inherited and changing interactions between state and society have powerfully but variably shaped the politics of proximity in the Canadian context, pointing towards the need for better understanding of how societal demands will influence policy change under conditions of rapid change. After describing policy histories and narratives at international and Canadian levels, the paper discusses three factors that have shaped ocean proximity politics in the institutions under 
examination and will likely continue to do so in Canada and elsewhere into the long-term future: (i) multiple biophysical and societal mobilities that challenge institutional responses; (ii) evidence, and normative arguments, about conservation and equity consequences of access regimes, often linked to studies of small-scale fisheries and nearby coastal communities; and (iii) and distributive, interest-based politics. The paper concludes by summarizing key findings and identifying four areas of future research in ocean proximity politics.

\section{Spatial proximity in global ocean governance}

\section{Inter-state conflict and cooperation: power, conservation and equity}

Viewed from a long-term perspective, the most powerful formal institutions governing the totality of the Earth and its oceans were generated through European colonialism and the modern state system. After enjoying widespread European acceptance for centuries of inter-state wars, the inter-imperialist doctrine of Mare Liberum, "freedom of the seas", that governed state claims to jurisdiction over areas limited to a relatively small distance from coastal shores was challenged through the twentieth century by a new round conflicts. States began to more aggressively assert their claims and defend extractive activities of particular domestic interests. Through social and political conflict and cooperation, new state politics merged with and developed through old relationships and institutions of ocean control (Campling and Colás 2018). These interactions culminated in the United Nations-authorized EEZs, a global zoning framework for governing engagement with the seas. Following negotiations and unilateral declarations, states increasingly accepted the EEZ regime of global ocean governance as customary international law in the 1970s and ultimately in the multi-lateral UNCLOS in 1982 (Copes 1981).

A new ocean governance regime was thus built, consolidating for nation-states massive opportunities for control, conservation and distributing commercial opportunities. More than $95 \%$ of global fisheries resources were brought under coastal state jurisdiction, ushering in widespread intensification of existing and new state and societal interventions into the oceans through the geographic extension, redefinition, reorganization and reinstitutionalization of fisheries management (Bavington 2009; Johnsen et al. 2009; Johnsen 2014). A key objective of the negotiators of UNCLOS was to eliminate overfishing by distant-water fleets perceived by coastal states as primary causes of reducing many stocks near their shores and to enable more equitable allocation of fisheries resources for and within nations closest to such resources (Copes 1981). In Eastern Canada, fishers responded to the increasing intensification of fishing by European trawlers in the northwest Atlantic in the post-war period by demanding that the federal government extend exclusive fishing zone from 3 miles to a 12 mile limit (Copes 1981; Hage 1984; De Yturriage 1997; Wright 1997). In addition to multi-lateral organizations and fisheries management ministries, then, societal actors such as fisher associations, corporations and unions mediated relations between society and the sea through the development of norms embedded in UNCLOS. While commercial and capitalistic principles and interests were served well through UNCLOS and related processes (Campling and Colás 2021), coastal communities and small-scale fisheries constituted key elements in addressing the problem of who benefits from oceans and fisheries.

\section{Fisheries for whose benefit?}

Demands for ensuring an equitable distribution of benefits was an important, though not uniform, justification for the extension of state claims approximately out to 200 nautical miles from coastal shores. Equity was often embedded in calls for provision of greater benefits for populations typically most disadvantaged in terms of social development, including developing nations, fisheries-dependent populations in coastal communities and consumers in countries dependent on fish imports (Copes 1981). For example, in anticipation of the extension of coastal state jurisdiction to 200 nautical miles in the 1970 s, the European Commission developed proposals that included the objective "To protect the income and employment of certain coastal communities" (Berg 1999: 6, 8, 24-25). Believing that a rapid exhaustion of resources would likely result from the implementation of an equal access principle among member states, the draft exemption proposal would have authorized member states to restrict fishing in a 12-mile limit to protect fishermen's access to the proximate zone, giving preferential treatment to regions especially dependent upon fishing including Greenland, Ireland, Northern Ireland, Scotland and the rest of the UK. The provision was rejected by member states but a resolution concerning the protection of fishermen within the 12-mile zone that required the CFP to take into account the "vital needs of local Communities particularly dependent on fishing" was approved (Berg 1999:27). These policies developed into the Hague Preferences, a Common Fisheries Policy Mechanism that enabled the adjustment of national fishing quotas to provide additional opportunities to fisheries-dependent areas (Harris 1990). Fishermen and coastal communities were also active agents in the construction and reconstruction of such international and national management directives. Like in Europe, fishing association representatives in Canada lobbied state representatives to extend jurisdiction and to introduce regulations that fit their temporal and spatial needs of the day (Hage 1984; Wright 1997). 
These interactions between particular societal interests and states help explain why coasts and oceans are key sites in political struggles over the distribution of risks, costs and opportunities and a site for competitive innovation and experimentation in spatial governance (Campling and Colás 2021: p. 2). Just as it formed a core basis for coastal state claims, proximity logically extends to justify serving the interests and needs of coastal communities and small-scale fisheries whose capacity and reach tends to be limited to relatively nearshore activity. Notions of adjacency rights can thus just as easily be used to justify and legitimize claims of coastal interests and identities like communities and smallscale fisheries as it can be used by and for nation-states, including with reference to material access, use and benefits. This has profound potential for influencing fisheries management. As Davis and Wagner explain:

"Adjacency was a key reference point in the recognition and distribution of access priority and management authority within the Law of the Sea negotiations and outcomes. In large measure, adjacency goes handin-glove with a claim that the people of coastal nationstates have a history of socio-economic dependence on and continuous use of marine-based resources" (Davis and Wagner 2006: 477).

In addition to finding their way into UNCLOS and related processes, coastal communities and small-scale fisheries have featured prominently in other key United Nations processes for similar reasons of material access, dependence and opportunity. While not using the terms proximity or adjacency, Article 6.18 of the UN FAO Code of Conduct for Responsible Fisheries implies that nation-states support the use needs of small-scale fisheries and communities that are invariably adjacent to marine resources (FAO 1995). More recently, the FAO's Technical Consultation on International Guidelines for Securing Sustainable Small-Scale Fisheries identified principles for promoting small-scale fisheries worldwide, with an emphasis on remote, rural communities and vulnerable groups such as Indigenous people and women. Principles of implementation were subsequently instituted in the UN FAO Voluntary Guidelines for Securing Sustainable Small-Scale Fisheries in the Context of Food Security and Poverty Eradication (FAO 2015). These guidelines call for attention to, and recognition of, communal and Indigenous rights and prioritizing their access to adjacent fisheries and for their inclusion in decisions that pertain to managing fisheries adjacent to them (FAO 2015). Similar references are embedded in various provisions, such as 5.3 and 5.7, calling on states to secure preferential access for small-scale fisheries, including both protecting existing and creating various new forms (e.g. informal and formal) of tenure rights for small-scale fishers (FAO 2015:5 \& 6). Moreover, in addition to highlighting material benefit, the principle of conservation effectiveness is noted in several provisions implying that small-scale fisheries can and should serve as active, responsible and effective stewards of sustainable resource management (FAO 2015:3 \& 7). Like states, coastal communities and small-scale fisheries can be perceived as actors with special ways and means to address problems of control, problems of social development for particular communities and productive interests, and problems of conservation.

\section{Proximity policies for eastern Canada's fisheries}

\section{"We want to build the 200-mile zone from the coast out"}

Proximity is a powerful principle of ocean governance. Below, we examine proximity policy emergence and history in Canada. The fisheries management agency responsible for fisheries in Canada's eastern regions has formally incorporated robust references to adjacency explicitly and implicitly since the 1970s and 1980s as the Government of Canada consolidated ways and means to implement UNCLOS provisions of resource control, conservation and distribution.

As the Government of $\mathrm{Canada}^{3}$ engaged and implemented UNCLOS, it not only shifted policy towards antecedents of neoliberalism through practices of rationalization, efficiency and conservation. Some policies have been responsive to the interests and demands of the inshore smaller-scale fishery. This was particularly true for the eastern fisheries, where a relatively robust set of policies developed that favored the small-scale sector and the coastal communities from where these smaller vessels operated and to where they often landed fish (Barnett et al. 2017). Spatial relations were at the heart of such policy histories. In a speech about northern cod in 1977, Minister LeBlanc, an MP elected to represent a coastal region of New Brunswick, reflected (with gendered language) on why proximity and mobility matters for him and how this is connected to inshore fishermen and coastal communities:

"Who gets first crack at these fish? Here I must say... that I have a clear bias for the inshore fisherman. Not

\footnotetext{
${ }^{3}$ Indigenous peoples' access to fisheries in a settler context such as Canada requires consideration of distinct constitutional and political developments (Bennett et al. 2018). The adjacency principle has also been incorporated into Comprehensive Land Claims Agreements in Canada. The Nunavut Land Claims Agreement, signed by the Inuit of the Nunavut Settlement Area and the government of Canada in 1993, recognizes the importance of access to the fishery, particularly the importance of adjacency as a criterion, for economic development in Nunavut (Jackman et al. 2002:42; Nunavut Land Claims 1993:136).
} 
because of some romantic regard, not because of his picture on the calendars, but because he cannot travel far after fish, because he depends on fishing for his income, because his community in turn depends on his fishery being protected" (Parsons 1993:123).

In a speech to the Halifax Board of Trade in 1979, he put these conversations into a regional context, highlighting characteristics that would distinguish policy paths on the Atlantic from those for the Pacific and North in important ways:

"in Atlantic fisheries generally, our policies support ownership of vessels by individual fishermen, or by the companies they form, rather than by processing companies. We have saved quotas and licenses to give the inshore and midshore men... the chance to move up to better boats and a better fishery. We want to build the 200-mile zone from the coast out" (Gough 2007: 322).

\section{Institutionalization}

Over time, and through successive governments, policy makers and policy texts began to more explicitly refer to the concept of adjacency (Parsons 1993:122). The 1984 Atlantic Groundfish Management Plan makes an early formal reference to the principle of adjacency alongside equity as an explicit criterion in resource access and distribution decisions, stating that:

"Allocation of fishery resources will be on the basis of equity taking into account adjacency to the resource, the relative dependency of coastal communities and the various fleet sectors upon a given resource, and economic efficiency and fleet mobility" (Blackwood 1996:37).

Through 1980s and early 1990s, the direct and indirect use of the concept spread further. While not explicitly referring to the term adjacency, the Fleet Separation Policy of 1979 calls for the separation of fisheries harvesting ownership from processing ownership in part because of the influence of closeness/distance. It required the discontinued issuance of new fishing licences (meant for vessels $<65 \mathrm{ft}$ in length) to more mobile corporations and processing companies (DFO 2001) that have greater ability to extract benefits from their activities from coastal communities. The Owner-Operator Policy, which appears to have evolved first in Quebec in the 1980's and later in the Maritimes and in Newfoundland's Gulf of St. Lawrence fishing regions, promotes individually operated inshore fleets by requiring that license holders (of vessels $<65 \mathrm{ft}$ in length) personally fish their quotas (Gough 2007:326). Spatial proximity principles were also embedded in residency requirements in licensing policies, whereby "residency, area of historical fishing or home port may be used as eligibility requirements when new or replacement licenses are issued" (DFO 1996a, b). It was embedded further in the development of policies for DFO administrative areas or Sectors starting in 1982 "to control access among various fleet sectors and allow for a suitable balance between the resources available and the fishing effort" within the boundaries of a specified sector (DFO 2001).

The area/sector policy had a major influence on the geographic relationship between fishers subject to its rules and the places they were authorized to fish. It eradicated the practice whereby license holders, mainly small vessel fleets, could fish almost anywhere on the Atlantic Coast where quotas were available, and instituted a more restricted but structured system which, with some exceptions such as authorized and historical overlaps, required license holders to fish in a defined fishing area or zone where their home port was located (Parsons 1993:331; DFO 2001). The policy restricted the mobility of the inshore groundfish fleet to DFO administrative areas of their home port and where they held licenses, promoting a formal regulatory link between homeport and adjacent fishing grounds. It also promoted a link between homeport region and adjacent fishing grounds by making licenses for vessels less than 65 feet non-transferable among areas/ Sectors (Parsons 1993:137). The increasing unofficial "violation" of the adjacency principle by mobile fishers was at the heart of these early policy changes. As a policy summary noted, "The increasing mobility and catching capability of certain parts of the fleet created growing opposition to their 'roaming' outside their own area and harvesting quotas before resident operators were ready to fish" (DFO 2001: 10). Residency, area of historical fishing or home port may also be used as eligibility requirements when new or replacement licenses are issued (DFO 1996a, b, 2018a). The policy "requires that inshore licenses be re-issued only to fishers who reside in or have sufficient attachment to the same DFO administrative area as the current license-holder (residency, home port or area of historical fishing provision)" (DFO 2001: 19).

Proximity and adjacency has become explicit in:

1. Prominent reports that address access criteria, such as Dunne Task Force (Blackwood 1996:78) and the Harris Report (Harris 1990);

2. Expansive policy directives such as The Commercial Fisheries Licensing Policy for Eastern Canada (DFO 1996a, b), the New Access Framework (DFO 2002) and the Policy for Preserving the Independence of the Inshore Fleet in Canada's Atlantic Fisheries (PIIFCAF) (DFO 2010);

3. Management and decision-making frameworks such as formal integrated fisheries management plans (IFMPs) 
for Northern shrimp (Gough 2007:447; Foley et al. 2015; Keenan and Carruthers 2015; Foley and Mather 2016; Carruthers et al. 2019) and herring (DFO 2018a, b).

The expansive policy directives are particularly important and influence other decision-making paths such as integrated fisheries management plans (IFMPs). The New Access Framework, for example, includes adjacency as one of the four criteria to "guide all decisions on new or additional access to Atlantic commercial fisheries which have undergone substantial increases in resource abundance or landed value" (DFO 2002). The framework defines adjacency for decisionmakers in the following way:

"Priority of access should be granted to those who are closest to the fishery resource in question. The adjacency criterion is based on the explicit premise that those coastal fishing communities and fishers in closest proximity to a given fishery should gain the greatest benefit from it, and on the implicit assumption that access based on adjacency will promote values of local stewardship and local economic development" (DFO 2002).

While the definition is useful, interpretive disputes emerged as a persistent source of contention. In reviewing allocation processes for the Northern shrimp, for example, various producer interests tended to "interpret the adjacency principle in ways that most optimizes their own positions" (Barrow et al. 2001:40-41). Adjacency and other criteria for access and allocation were evaluated as being vague and illdefined, with considerable confusion as to the meaning of adjacency for some observers and interest groups (Jackman et al. 2002; Keenan and Carruthers 2015; Foley et al. 2017). Efforts to resolve these issues fully have met with limited success, partly because of challenges in developing universally acceptable definitions and solutions (Jackman et al. 2002:15-16, 73). Even the idea of according less weight to the adjacency principle in situations where interests relied on more distant resources (e.g. in the case of offshore fisheries) has met challengers (Government of Newfoundland and Labrador 2002). While this definition points towards a relatively robust textual commitment to proximity, the ability of groups to benefit from living and changing materialities is affected by a range of societal factors beyond spatial proximity (Parlee et al. 2021

\section{The living, moving materiality of distributional (in)equity}

The ability of coastal states to effectively and ethically manage and govern sovereign rights and responsibilities created and maintained through UNCLOS has raised critical questions of law, governance and sustainability in recent decades (Alcook 2002; Tan-Mullins 2007; Johnsen et al. 2009; Lam and Pauly 2010; Chircop 2011; Menon et al. 2016). Imminent and ongoing rapid climate and oceanic change will further intensify questions and challenges for governance institutions. In this context, proximity will likely be particularly affected, among other forces, by (i) mobilities of biophysical and societal processes, (ii) narratives of conservation advantage and problem solving for coastal communities and other related interests such as small-scale fisheries and (iii) distributive politics.

\section{Mobilities}

Mobilities of marine life, fishing capital and fleets, and workers all make proximity politics more complicated under conditions of change. As Steinberg observes, to understand nation-state territories, "one must go beyond tracing the spatially fixed activities...or the discursive strategies though which the territory is made to appear natural. One must also trace the acts of movement that occur within, across and outside the territory's boundaries and the designation of spaces of movement as beyond territorial control" (Steinberg 2009: 467). Mobilities structure, enliven, challenge and change the relationship between space and sovereignty (Havice 2018). In the Canadian context, for example, one major access criteria report contrasted managing lobster fishing (relatively close to shore) to tuna fishing (generally pursued well offshore) in part because of the different mobilities of each species, implying that as distances increase the adjacency principle ought to have less significance in allocation decisions (Jackman et al. 2002:14). The report recommended that the use of the adjacency principle in resource access and distribution was more logical and appropriate for sedentary species such as lobster and crab and less logical or appropriate in more migratory species (Jackman et al. 2002:81).

This creates two further challenges related to socialspatial relations. The first is related to more complex social situations in which people migrate or live and work in relatively mobile situations (which, for example, make residency requirements a problem). People move temporarily and for more or less longer periods, living in areas adjacent to fishing areas for temporary periods, sometimes limited to the fishing season. Settlement and residency patterns are not static. Seasonal migration is a common livelihood strategy in small-scale fisheries (FAO 2015:x) and the social and demographic characteristics of coastal fishing communities are changing, including with more dispersed occupational communities embedded in a more diverse economy (Symes and Phillipson 2009:2). Despite residency and home port requirements in Canada, the 
question of who is adjacent is not always straightforward in social-ecological contexts in which people are on the move. The second challenge is related to the mobility of capital, which has defined class, household and gender relations for centuries of commercial fishing in places like Newfoundland (Foley 2019a, b). Dramatic increases of strategies by capital investors to redirect benefits from owner-operator and coastal communities to corporate enterprises, aided in large part by the use of contract law to create controlling agreements between owner-operators and investors to circumvent owner-operator policy, have accelerated in recent decades (Edwards and Pinkerton 2019; Barnett et al. 2017). Increasing mobility of capital is driven in part by the problem of the spatial fix, whereby forces push to extend commercial rights to new ocean resources and spaces as control, conservation and sharing get strained in existing relations (Campling and Colás, 2021).

\section{Conservation and co-management}

Adjacency creates certain governance advantages too. Research by marine social scientists suggests that people who live permanently near resources often have a long-term interest in using those resources sustainably (See, for example: McCay and Acheson 1987; Berkes 1989; Ostrom 1990; Pinkerton 1999). This research suggests that local communities are capable of designing institutions that can limit access to adjacent fish resources equitably and effectively (Pinkerton 1999). For similar reasons, two of the eight principles for how common pool resources can be equitably and sustainably governed in a community include defining clear group boundaries and matching rules governing use to local needs and conditions (Ostrom, 1990).

Some researchers have long argued that proximity justifies devolution and power sharing to certain coastal interests like small-scale fisheries. Almost 40 years ago, Panayotou argued that "The revival and rejuvenation of traditional community rights over coastal resources offer, perhaps, the best possible management option for scattered, remote and fluid, small-scale fisheries" (Panayotou 1982). More recently, Daniel Pauly argues for the advantages of adjacency while promoting new visions for future fisheries:

"because small-scale fishers invariably live close to their fishing grounds, and depend on the resource therein and on no others, they can be (re-)connected, if need be, with the idea of caring for the resources; which the hired hands on board of industrial vessels cannot afford to do. Combined with the obvious advantage of adjacency (short sailing time, and hence limited fuel consumption, if fuel is used), this is a major reason why small-scale fisheries have the potential of becoming the fisheries of the future" (Pauly 2011:17).
Echoing Christy's analysis of Territorial Use Right Fisheries (Christy 1982), Pinkerton similarly argues that: "Management problems are best solved when rights accrue to the parties best suited to be accountable to sustainable management practices and to resolve inter-sectoral conflicts. These usually turn out to be those parties with long-term relationships to, and dependence on, local fishing territories..." (Pinkerton 1999:340). For similar reasons, adjacency is included as an ethical attribute for evaluating and comparing the status and sustainability of fisheries (Pitcher and Preikshot 2001). The idea that government should share more responsibility with place-based communities and regions most affected by resource policies or decisions is thus grounded in evidence suggesting that proximity enhances legitimacy and effectiveness (Pinkerton 2019). While proximity justifies new power sharing arrangements such as comanagement, the application of principles of proximity, and their precise relations to equity and conservation, is also subject to challenges of distributive and interest-based politics.

\section{Distributive politics}

Fisheries governance is politicized through UNCLOS and state management institutions in wide-ranging and diverse ways. The institutional efforts of coastal states to create, manage and govern sovereign rights and responsibilities through UNCLOS have become "entangled in a web of different instruments, stakeholder groups, policies and sciences that made panoptic control and management impossible" with "rationality, truth and decision making in the system [becoming] objects for negotiation between scientists, users, politicians and bureaucrats, and consequently the rational foundation of management became challenged" (Johnsen et al. 2009: pp. 14-15). Establishing claims and rights of engagement, use and management by proximity lays bare ways in which the relationship between land and sea is not reducible to the static and binary inscriptions and divisions that characterize formal legal arrangements such as UNCLOS (Boucquey et al. 2016; Steinberg et al. 2020). Critical political economy and political ecology analyses have identified how multiple dimensions of proximity, distance and mobility interact with old and new discursive and material transformations of oceans as a frontier of state and capital resource extraction, financialization and grabbing (Bennett et al. 2015; Knott and Neis 2017; Barbesgaard 2018; Foley and Mather 2019; Havice and Zalik 2018). While discourses, narratives and practices of neoliberalism tend to receive scrutiny in terms of consequences for power relations, conservation and equity (Pinkerton 2015; Pinkerton and Davis 2015; Boucquey 2017), the consequences of the politics of proximity in changing oceans for power, conservation and equity are subject to relatively little research and policy attention. 
Over longer periods of time, proximity politics will become more complex as climate change alters the geographic patterns and distributions of fish habitats and populations. Policy makers at international and national levels are unprepared for the shifting geographic distributions in marine animals in the coming decades. As Pinsky and colleagues observe, changes in geographic distributions of fish will create potential for conflict between and within countries, in part because "existing fisheries management and governance are largely predicated on population geographies that remain broadly static through time" (Pinsky et al. 2018:1189). Existing international legal and policy frameworks for fisheries, including UNCLOS, do not account for changing or fluctuating distributions of marine species (Pinsky et al. 2018:1190). Management authorities will therefore need to acquire reliable projections of species shifts, take account of uncertainties and plan for cooperative management under such changing conditions and scenarios of shared stocks (Gaines et al. 2018).

New politics of proximity will also likely be defined by contestation resulting from multi-criteria decision-making. The challenge of defining and applying multiple criteria for granting access rights and privileges emerged as a longstanding issue in Eastern Canada (Jackman et al. 2002). These challenges were compounded by the diverse interests and actors vying to define multiple access criteria. We can expect regionally specific state/societal actors and interactions to influence how principles of conservation and equity interact with proximity politics. Such actors and interactions will influence responses to change and uncertainty.

\section{Conclusion}

Climate and ocean change are putting increased pressure on governance actors and institutions to respond and adapt to change (Pinsky et al. 2018; Young et al. 2018). Centering analysis on proximity politics across and within colonial and nation-states, this paper contributes to a reinvigorated social science research agenda for fisheries (Bavinck et al. 2018; Jentoft 2020) and to broader literatures that have identified proximity as a key component of multidimensional spatialized narratives of distributional environmental injustice and justice (Walker 2009). This paper's findings support critical assessments that suggest it is necessary to understanding about the significance of how wider social and spatial contexts, including individuals, households, classes and organizations, are also implicated in the social patterns of environmental justice (Walker 2009). Understanding policy histories is one way to help enhance understanding of how past legacies constrain or enable opportunities for old and new actors to exert progressive influence over global ocean governance
(Campbell et al. 2016). By including narrative policy histories in international and national contexts, this paper demonstrates how state governance is not simply imposed on passive places, materials and people. Instead, they interact with, challenge and are rearticulated by social and biophysical forces. These interactions create potential for new "blue legalities" that build on old and new ways of knowing, understanding and relating to the world (Braverman and Johnson 2020).

More diverse sources and forms of knowledge and narratives are needed, however, to more comprehensively understand proximity politics and its relationship to other forces of change and continuity. For example, how social structures, relationships and struggles within and outside the state influence paths of development and change as it relates to fisheries requires further understanding (Bavinck et al. 2018; Parlee et al. 2021). For the study of proximity politics specifically, more research should:

1. Incorporate multiple sectors and alternative uses as competing demands for using ocean space through activities such as shipping, trade, slavery, bondage, aquaculture, wind farms and seafronts intensifies (Campling and Colás 2021);

2. Build better comparative, interdisciplinary and integrated understanding of proximity politics across different institutional, societal and biophysical contexts. Such comparative and integrated work should incorporate examining more diverse strategies and policies of proximity politics. It should also examine how proximity politics are impacted by other forces of change such as sea-level rise (Yusuf et al. 2014), oxygenation, infrastructure development, migration, class, labour, colonialism, gender, race and intersectionality. This research will benefit from richer engagements with and across natural sciences, social sciences (Jentoft 2020), blue humanities (e.g. DeLoughrey 2019; Alaimo 2019) and other inter and trans-disciplines and fields of research and policy.

3. Document past, existing and potential policy narratives and objectives to inform future governance and narrative deliberation. Narratives help define our thinking and action and prominent observers have called for "a new narrative for the ocean" (Lubchenco and Gaines 2019). Just as narratives of sharing and who benefits defines UNCLOS and Canadian policy histories, future struggles will likely center on powerful and competing narratives about proximity and its implications for control, conservation and material distribution of societal benefits.

4. Use any enhanced understanding of policy narratives to help inform collaborative research and action/policy networks. Such networks could include multiple groups, including Indigenous and local people, to build and/or 
resist particular policies. Narratives are not simply a source of policy development but can also act "as tools to resist certain policies or activities", including to "increase access or re-territorialize the ocean in ways that would favor some communities or certain groups" (Bennett 2019).

Narrative tools and rhetorical devices have always shaped modern, colonial, state and non-state ocean discourses, knowledge and governance about oceans. Narrative tools are also useful for evaluating adaptation options and building capacity for imagining and adapting to actual changes in the short, medium and long term (Nash et al. 2020; Spijkers et al. 2021). As the United Nations seeks to achieve major scientific and developmental goals (UN 2020; FAO 2020; Singh et al. 2021), documenting and sharing policy histories and narratives could help influence global and local ocean governance. This paper provides opportunities for moving in this direction.

Acknowledgements The ideas in this paper have emerged over many years of research and collaboration, particularly with Charlie Mather to whom I send many thanks. I also wish to thank Richard Nyiawung, Evan Andrews, Barb Neis, Ian Stewart, Megan Bailey, María Andrée López Gómez, Emily Reid-Musson, Christine Knott and Gerald Singh for taking the time to provide feedback on earlier drafts.

Funding The research leading to these results received funding from the Government of Newfoundland and Labrador Department of Fisheries, Forestry and Agriculture. The research also benefited from the engagement and support of the Ocean Frontier Institute's Informing Governance Responses in a Changing Ocean project.

Availability of data and material Yes/documents.

\section{Declarations}

Ethics approval Not applicable.

Consent to participate Not applicable.

Consent for publication Not applicable.

Competing interests The authors declare no competing interests.

Open Access This article is licensed under a Creative Commons Attribution 4.0 International License, which permits use, sharing, adaptation, distribution and reproduction in any medium or format, as long as you give appropriate credit to the original author(s) and the source, provide a link to the Creative Commons licence, and indicate if changes were made. The images or other third party material in this article are included in the article's Creative Commons licence, unless indicated otherwise in a credit line to the material. If material is not included in the article's Creative Commons licence and your intended use is not permitted by statutory regulation or exceeds the permitted use, you will need to obtain permission directly from the copyright holder. To view a copy of this licence, visit http://creativecommons.org/licenses/by/4.0/.

\section{References}

Acheson, James M. 1975. The lobster fiefs: Economic and ecological effects of territoriality in the Maine lobster industry. Human Ecology 3 (3): 183-207.

Alaimo, Stacy. 2019. Introduction: Science studies and the blue humanities. Configurations 27 (4): 429-432.

Alcook, Frank. 2002. Bargaining, uncertainty, and property rights in fisheries. World Politics 54: 437-461.

Allison, Eddie H. 2001. Big laws, small catches: Global ocean governance and the fisheries crisis. Journal of International Development 13 (7): 933-950.

Barnett, Allain J., Robin A. Messenger, and Melanie G. Wiber. 2017. Enacting and contesting neoliberalism in fisheries: The tragedy of commodifying lobster access rights in Southwest Nova Scotia. Marine Policy 80: 60-68.

Barrow, Julia, G. E. Jefferson, M. D. Eagles, and G. J. Stevens. 2001. Allocation of harvesting rights in three Atlantic Canada marine fisheries. FAO fisheries technical paper, 32-57.

Barbesgaard, Mads. 2018. Blue growth: Savior or ocean grabbing? The Journal of Peasant Studies 45 (1): 130-149.

Bavinck, Maarten, Joyeeta Gupta. 2014. Legal pluralism in aquatic regimes: A challenge for governance. Current Opinion in Environmental Sustainability 11: 78-85.

Bavinck, Maarten, Svein Jentoft, and Joeri Scholtens. 2018. Fisheries as social struggle: A reinvigorated social science research agenda. Marine Policy 94: 46-52.

Bavington, Dean. 2009. Managing to endanger: Creating manageable cod fisheries in Newfoundland \& Labrador, Canada. Maritime Studies 7 (2): 99-119.

Bennett, Nathan J. 2019. In political seas: Engaging with political ecology in the ocean and coastal environment. Coastal Management 47 (1): 67-87.

Bennett, Nathan James, Hugh Govan, and Terre Satterfield. 2015. Ocean grabbing. Marine Policy 57: 61-68.

Bennett, Nathan J., Maery Kaplan-Hallam, Gerry Augustine, Natalie Ban, Dyhia Belhabib, Irene Brueckner-Irwin, Anthony Charles, et al. 2018. Coastal and Indigenous community access to marine resources and the ocean: A policy imperative for Canada. Marine Policy 87: 186-193.

Berg, Astrid, ed. 1999. Implementing and enforcing European fisheries law: the implementation and the enforcement of the Common Fisheries Policy in the Netherlands and in the United Kingdom. Martinus Nijhoff Publishers.

Berkes, Fikret. 1989. Common property resources. Ecology and community-based sustainable development. London: Belhaven.

Biermann, Frank. 2014. Earth system governance: World politics in the Anthropocene. MIT Press.

Blackwood, Glenn. 1996. Past and future goals and objectives in the allocation of the northern cod resource. Unpublished Master's thesis (St. John's: Memorial University of Newfoundland).

Boucquey, Noëlle. 2017. 'That's my livelihood, it's your fun': The conflicting moral economies of commercial and recreational fishing. Journal of Rural Studies 54: 138-150.

Boucquey, Noëlle., Luke Fairbanks, Kevin St Martin, Lisa M. Campbell, and Bonnie McCay. 2016. The ontological politics of marine spatial planning: Assembling the ocean and shaping the capacities of 'community' and 'environment.' Geoforum 75: $1-11$

Burch, Sarah, Aarti Gupta, Cristina YA. Inoue, Agni Kalfagianni, Åsa. Persson, Andrea K. Gerlak, Atsushi Ishii, et al. 2019. New directions in earth system governance research. Earth system governance 1: 100006.

Braverman, Irus, and Elizabeth R. Johnson, eds. 2020. Blue legalities: the life and laws of the sea. Duke University Press. 
Campbell, Lisa M., Noella J. Gray, Luke Fairbanks, Jennifer J. Silver, Rebecca L. Gruby, Bradford A. Dubik, and Xavier Basurto. 2016. Global oceans governance: New and emerging issues. Annual Review of Environment and Resources 41: 517-543.

Campling, Liam, and Elizabeth Havice. 2014. The problem of property in industrial fisheries. The Journal of Peasant Studies 41 (5): 707-727.

Campling, Liam, and Alejandro Colás. 2018. Capitalism and the sea: Sovereignty, territory and appropriation in the global ocean. Environment and Planning d: Society and Space 36 (4): 776-794.

Campling, Liam, and Alejandro Colás. 2021. Capitalism and the sea: the maritime factor in the making of the modern world. Verso Books.

Campling, Liam, Elizabeth Havice, and Penny McCall. Howard. 2012. The political economy and ecology of capture fisheries: Market dynamics, resource access and relations of exploitation and resistance. Journal of Agrarian Change 12 (2-3): 177-203.

Canadian Association of Prawn Producers (CAPP). (n.d). Stay the course. Retrieved from www.staythecourse.ca

Carruthers, Erin H., Courtenay E. Parlee, Robert Keenan, and Paul Foley. 2019. Onshore benefits from fishing: Tracking value from the northern shrimp fishery to communities in Newfoundland and Labrador. Marine Policy 103: 130-137.

Chircop, Aldo. 2011. Managing adjacency: Some legal aspects of the relationship between the extended continental shelf and the International Seabed Area. Ocean Development \& International Law 42 (4): 307-316.

Christy, Francis T. 1982. Territorial use rights in marine fisheries: definitions and conditions. Vol. 227. Food \& Agriculture Org.

Cisneros-Montemayor, Andrés M., Marcia Moreno-Báez, Gabriel Reygondeau, William WL. Cheung, Katherine M. Crosman, Pedro C. González-Espinosa, Vicky WY. Lam, et al. 2021. Enabling conditions for an equitable and sustainable blue economy. Nature 591 (7850): 396-401.

Copes, Parzival. 1981. The impact of UNCLOS III on management of the world's fisheries. Marine Policy 5 (3): 217-228.

Daly, Jack, Christine Knott, Poppy Keogh, and Gerald G. Singh. 2021. Changing climates in a blue economy: assessing the climateresponsiveness of Canadian fisheries and oceans policy. Marine Policy 131: 104623.

Davis, Anthony, and John Wagner. 2006. A right to fish for a living? The case for coastal fishing people's determination of access and participation. Ocean \& Coastal Management 49 (7-8): 476-497.

Deloughrey, Elizabeth. 2019. Toward a critical ocean studies for the Anthropocene. English Language Notes 57 (1): 21-36.

DFO. 1996a. Atlantic Fisheries Licensing, http://www.dfo-mpo.gc. $\mathrm{ca} / \mathrm{fm}$-gp/policies-politiques/licences-permis/ch1-eng.htm\#SIX , (Ottawa: Department of Fisheries and Oceans)

DFO. 1996b. Commercial fisheries licensing policy for Eastern Canada. http://www.dfo-mpo.gc.ca/fm-gp/policies-politiques/licen ces-permis/ch3-eng.htm, (Ottawa: Department of Fisheries and Oceans).

DFO. 2001. Fisheries Management Policies on Canada's Atlantic Coast. A Summary of policies, acts and agreements in effect on September 30, 2001 that pertain to the management of the fisheries on Canada's Atlantic Coast. https://waves-vagues.dfo-mpo. gc.ca/Library/40675208.pdf (Ottawa: Department of Fisheries and Oceans)

DFO. 2002. New Access Framework, http://www.dfo-mpo.gc.ca/fmgp/policies-politiques/access-acces-eng.htm (Ottawa: Department of Fisheries and Oceans).

DFO. 2010. Policy for Preserving the Independence of the Inshore Fleet in Canada's Atlantic Fisheries, http://www.dfo-mpo.gc.ca/ reports-rapports/regs/piifcaf-policy-politique-pifpcca-eng.htm (Ottawa: Department of Fisheries and Oceans).
DFO. 2018a. "Integrated fisheries management plans," http://www. dfo-mpo.gc.ca/fm-gp/peches-fisheries/ifmp-gmp/index-eng.htm, (Ottawa: Department of Fisheries and Oceans).

DFO. 2018b. Fisheries licensing policy Newfoundland and Labrador. http://www.dfo-mpo.gc.ca/reports-rapports/regs/licences-permis/ nfld-Labrador-tn-labrador-eng.htm\#toc 14, (Ottawa: Department of Fisheries and Oceans).

Dubik, B.A., E.C. Clark, T. Young, S.B.J. Zigler, M.M. Provost, M.L. Pinsky, and K.S. Martin. 2019. Governing fisheries in the face of change: Social responses to long-term geographic shifts in a US fishery. Marine Policy 99: 243-251.

Durrenberger, E. Paul., and Gísli. Pálsson. 1987. Ownership at sea: Fishing territories and access to sea resources. American Ethnologist 14 (3): 508-522.

FAO. 1995. Code of conduct for responsible fisheries. Food \& Agriculture Org

FAO. 2015. Voluntary guidelines for securing sustainable smallscale fisheries in the context of food security and poverty eradication. Rome: Food and Agriculture Organization of the United Nations.

FAO. 2020. Sustainable development goals: target 14.b. http://www. fao.org/sustainable-development-goals/indicators/14b1/en/

Farmery, Anna K., Edward H. Allison, Neil L. Andrew, Max Troell, Michelle Voyer, Brooke Campbell, Hampus Eriksson, Michael Fabinyi, Andrew M. Song, and Dirk Steenbergen. 2021. Blind spots in visions of a "blue economy" could undermine the ocean's contribution to eliminating hunger and malnutrition. One Earth 4 (1): 28-38.

Foley, Paul. 2019a. A Coxian perspective on transnational business governance interactions: counter-hegemonic certification movements in fisheries. In Stepan Wood, Rebecca Schmidt, Errol Meidinger, Burkard Eberlein, and Kenneth W. Abbott, (Eds). Transnational business governance interactions. Edward Elgar Publishing.

Foley, Paul. 2019b. Social-ecological reproduction and the substance of life in commodity frontiers: Newfoundland fisheries in world market shifts. Capital \& Class 43 (4): 543-560.

Foley, Paul, and Charles Mather. 2016. Making space for community use rights: Insights from "community economies" in Newfoundland and Labrador. Society \& Natural Resources 29 (8): 965-980.

Foley, Paul, and Charles Mather. 2019. Ocean grabbing, terraqueous territoriality and social development. Territory, Politics, Governance 7 (3): 297-315.

Foley, Paul, Charles Mather, and Barbara Neis. 2015. Governing enclosure for coastal communities: Social embeddedness in a Canadian shrimp fishery. Marine Policy 61: 390-400.

Foley, Paul, Charles Mather, Robyn Morris, and Jamie Snook. 2017. Shrimp allocation policies and regional development under conditions of environmental change: insights for Nunatsiavutimmuit (St. John's: The Leslie Harris Centre of Regional Policy and Development, Memorial University of Newfoundland) Available from http://www.mun.ca/harriscentre/reports/FOLEY_ARF_15_ 16.pdf.

Gaines, Steven D., Christopher Costello, Brandon Owashi, Tracey Mangin, Jennifer Bone, Jorge García Molinos, Merrick Burden, et al. 2018. Improved fisheries management could offset many negative effects of climate change. Science advances 4 (8): eaao1378.

Gough, Joseph. 2007. Managing Canada's fisheries: From early days to the year 2000. Fisheries and Oceans, Canada. Sillery: Éditions du Septentrion.

Government of Newfoundland and Labrador. 2002. Minister responds to Independent Panel on Access Criteria (IPAC) report. http:// www.releases.gov.nl.ca/releases/2002/fishaq/0405n04.htm (St. John's: Government of Newfoundland and Labrador). 
Gray, Noella J. 2018. Charted waters? Tracking the production of conservation territories on the high seas. International Social Science Journal 68 (229-230): 257-272.

Hage, Robert. 1984. Canada and the law of the sea. Marine Policy 8 (1): $2-15$.

Haas, B., M. Mackay, C. Novaglio, L. Fullbrook, M. Murunga, C. Sbrocchi, J. McDonald, P.C. McCormack, K. Alexander, M. Fudge, and L. Goldsworthy. 2021. The future of ocean governance. Reviews in Fish Biology and Fisheries. https://doi.org/10. 1007/s11160-020-09631-x.

Havice, Elizabeth. 2018. Unsettled sovereignty and the sea: Mobilities and more-than-territorial configurations of state power. Annals of the American Association of Geographers 108 (5): 1280-1297.

Havice, Elizabeth, and Anna Zalik. 2018. Ocean frontiers: epistemologies, jurisdictions, commodifications. 219-235.

Knott, Christine, and Barbara Neis. 2017. Privatization, financialization and ocean grabbing in New Brunswick herring fisheries and salmon aquaculture. Marine Policy 80: 10-18.

Kooiman, Jan, Maarten Bavinck, Ratana Chuenpagdee, Robin Mahon, and Roger Pullin. 2008. Interactive governance and governability: An introduction. The Journal of Transdisciplinary Environmental Studies 7 (1): 1-11.

Jackman, Martha, Paul LeBlond, Gordon Munro, and David Locke Newhouse. 2002. Report of the Independent Panel on Access Criteria. Ottawa: Department of Fisheries and Oceans Canada.

Jentoft, Svein. 2020. Life above water: Small-scale fisheries as a human experience. Maritime Studies 19 (4): 389-397.

Johnsen, Jahn P. 2014. Is fisheries governance possible? Fish and Fisheries 15 (3): 428-444.

Johnsen, Jahn P., Peter Sinclair, Petter Holm, and Dean Bavington. 2009. The cyborgization of the fisheries. On attempts to make fisheries management possible. Maritime Studies 7: 9-34.

Keenan, Robert, and Carruthers, Erin. 2015. The northern shrimp fishery: the socio-economic importance of maintaining adjacency in allocation decisions, (St. John's: Fish, Food and Allied Workers-Unifor).

Kooiman, Jan, Svein Jentoft, Maarten Bavinck, and Roger Pullin. Fish for life: interactive governance for fisheries. Amsterdam university press, 2005.

Lam, Mimi E., and Daniel Pauly. 2010. Who is right to fish? Evolving a social contract for ethical fisheries. Ecology and Society 15 (3): 16.

Lehman, Jessica. 2016. A sea of potential: The politics of global ocean observations. Political Geography 55: 113-123.

Harris, Leslie. 1990. Independent review of the state of the northern cod stock, 42. Ottawa: Fisheries and Oceans Canada.

Lubchenco, Jane, and Steven D. Gaines. 2019. A new narrative for the ocean. Science 364 (6444): 911-911.

McCay, Bonnie J. (2011). Enclosing the fishery commons: from individuals to communities. Property in land and other resources. Lincoln Institute of Land Policy, Cambridge, Massachusetts, USA.

McCay, Bonnie J., and James M. Acheson, eds. 1987. The question of the commons: the culture and ecology of communal resources. University of Arizona Press.

Menon, Ajit, Maarten Bavinck, Johny Stephen, and R. Manimohan. 2016. The political ecology of Palk Bay Fisheries: Geographies of capital, fisher conflict, ethnicity and nation-state. Antipode 48 (2): 393-411.

Nash, Kirsty L., Jessica L. Blythe, Christopher Cvitanovic, Elizabeth A. Fulton, Benjamin S. Halpern, E.J. Milner-Gulland, Prue FE. Addison, Gretta T. Pecl, Reg A. Watson, and Julia L. Blanchard. 2020. To achieve a sustainable blue future, progress assessments must include interdependencies between the sustainable development goals. One Earth 2 (2): 161-173.
Nunavut Land Claims Agreement. 1993. Agreement between the Inuit of the Nunavut Settlement Area and Her Majesty in Right of Canada. Ottawa: The Tungavik and the Minister of Indian Affairs and Northern Development.

Ostrom, Elinor. 1990. Governing the commons: The evolution of institutions for collective action. Cambridge University Press.

Panayotou, Theodore. 1982. Management concepts for small-scale fisheries: Economic and social aspects. Rome: FAO.

Parlee, Courtenay E., Paul Foley, Maria Andree Lopez. Gomez, Ruyel Miah, Charles Mather, and Robert L. Stephenson. 2021. Full spectrum sustainability and a theory of access: integrating social benefits into fisheries governance. Marine Policy 134: 104764

Parsons, L. Scott. 1993. Management of marine fisheries in Canada Canadian Bulletin of Fisheries and Aquatic Sciences No. 225. NRC Research Press.

Pauly, Daniel. 2011. Forward. In World small-scale fisheries: contemporary visions, ed. R. Chuenpagdee. Delft: Eburon.

Peters, Kimberley. 2020. The territories of governance: Unpacking the ontologies and geophilosophies of fixed to flexible ocean management, and beyond. Philosophical Transactions of the Royal Society B 375 (1814): 20190458.

Pinkerton, Evelyn. 1999. Directions, principles, and practice in the shared governance of Canadian marine fisheries. In Fishing places, fishing people: traditions and issues in Canadian small-scale fisheries, ed. D. Newell and R. Ommer. Toronto: University of Toronto Press.

Pinkerton, Evelyn. 2015. The role of moral economy in two British Columbia fisheries: Confronting neoliberal policies. Marine Policy 6: 410-419.

Pinkerton, Evelyn. 2019. Legitimacy and effectiveness through fisheries co-management. In The future of ocean governance and capacity development (pp. 333-337). Brill Nijhoff

Pinkerton, Evelyn, and Reade Davis. 2015. Neoliberalism and the politics of enclosure in North American small-scale fisheries. Marine Policy 61: 303-312.

Pinsky, Malin L., Gabriel Reygondeau, Richard Caddell, Juliano Palacios-Abrantes, Jessica Spijkers, and William WL. Cheung. 2018. Preparing ocean governance for species on the move: policy must anticipate conflict over geographic shifts. Science 360 (6394): 1189-1191.

Pitcher, Tony J., and David Preikshot. 2001. RAPFISH: A rapid appraisal technique to evaluate the sustainability status of fisheries. Fisheries Research 49 (3): 255-270.

Posner, Eric, and Alan O. Sykes. 2010. Economic foundations of the law of the sea. American Journal of International Law 104: 569 .

Philip E., Steinberg (2009) Sovereignty Territory and the Mapping of Mobility: A View from the Outside. Annals of the Association of American Geographers 99(3) 467-495 10.1080/00045600902931702

Silver, Jennifer J., Noella J. Gray, Lisa M. Campbell, Luke W. Fairbanks, and Rebecca L. Gruby. 2015. Blue economy and competing discourses in international oceans governance. The Journal of Environment \& Development 24 (2): 135-160.

Singh, Gerald G., Harriet Harden-Davies, Edward H. Allison, Andrés M. Cisneros-Montemayor, Wilf Swartz, Katherine M. Crosman, and Yoshitaka Ota. 2021. Opinion: will understanding the ocean lead to "the ocean we want"? Proceedings of the National Academy of Sciences 118(5).

Spijkers, Jessica, Andrew Merrie, Colette CC. Wabnitz, Matthew Osborne, Malin Mobjörk, Örjan. Bodin, Elizabeth R. Selig, et al. 2021. Exploring the future of fishery conflict through narrative scenarios. One Earth 4 (3): 386-396. 
St. Martin, Kevin. 2009. Toward a cartography of the commons: Constituting the political and economic possibilities of place. The Professional Geographer 61 (4): 493-507.

Steinberg, Philip E., Berit Kristoffersen, and Kristen L. Shake. 2020. Edges and flows. In Blue Legalities, pp. 85-106. Duke University Press.

Symes, David, and Jeremy Phillipson. 2009. Whatever became of social objectives in fisheries policy? Fisheries Research 95 (1): 1-5.

Tan-Mullins, May. 2007. The state and its agencies in coastal resources management: The political ecology of fisheries management in Pattani, southern Thailand. Singapore Journal of Tropical Geography 28 (3): 348-361.

United Nations. 2020. International decade of ocean science for sustainable development: the science we need for the ocean we want. https://oceanconference.un.org/commitments/?id=15527

Walker, Gordon. 2009. Beyond distribution and proximity: Exploring the multiple spatialities of environmental justice. Antipode 41 (4): 614-636.

Werle, Dirk, Paul R. Boudreau, Mary R. Brooks, Michael JA Butler, Anthony Charles, Scott Coffen-Smout, David Griffiths et al.
2019. The future of ocean governance and capacity development. In The future of ocean governance and capacity development, pp. 1-4. Brill Nijhoff.

Wright, Miriam. 1997. Fishing in the Cold War: Canada, Newfoundland and the international politics of the twelve-mile fishing limit, 1958-1969. Journal of the Canadian Historical Association/revue De La Société Historique Du Canada 8 (1): 239-258.

Young, Oran R., D.G. Webster, Michael E. Cox, Jesper Raakjær, Lau Øfjord Blaxekjær, Níels. Einarsson, Ross A. Virginia, et al. 2018. Moving beyond panaceas in fisheries governance. Proceedings of the National Academy of Sciences 115 (37): 9065-9073.

Yusuf, Juita-Elena Wie., Burton St John, and Ivan K. Ash. 2014. The role of politics and proximity in sea level rise policy salience: a study of Virginia legislators' perceptions. Journal of Environmental Studies and Sciences 4 (3): 208-217.

Publisher's note Springer Nature remains neutral with regard to jurisdictional claims in published maps and institutional affiliations. 